\title{
SPIRORCHID AND SERPULID POLYCHAETES ARE CANDIDATES AS INVERTEBRATE HOSTS FOR MYXOZOA
}

\author{
Marianne Køie
}

Marine Biological Laboratory, University of Copenhagen, DK-3000 Helsingør, Denmark

While, in recent years, it has been routine to elucidate the life cycles of freshwater myxozoans, which have oligochaetes and bryozoans as invertebrate alternate hosts (Kent M.L., Andree K.B., Bartholomew J.L., El-Matbouli M., Desser S.S., Devlin R.H., Feist S.W., Hedrick R.P., Hoffmann R.W., Khattra J., Hallett S.L., Lester R.J.G., Longshaw M., Palenzeula O., Siddall M.E., Xiao C. 2001: J. Eukaryot. Microbiol. 48: 395-413), nobody has yet unravelled the life cycle of any of the numerous species which occur in marine fish (Lom J., Dyková I. 1992: Protozoan Parasites of Fishes. Elsevier, Amsterdam, 315 pp). Even though actinosporeans have been found in marine oligochaetes (Hallett S.L., Lester R.J.G. 1999: Int. J. Parasitol. 29: 419-427; Hallett S.L., Erséus C., Lester R.J.G. 1999: Syst. Parasitol. 44: 49-57) it is expected that non-oligochaete invertebrates, especially polychaetes, may act as invertebrate hosts for several of the marine species of the Myxozoa. The only known examples of marine non-oligochaete, invertebrate myxozoan hosts are the sipunculid worm Nephasoma minuta (Keferstein) (syn.: Petalostoma minutum) from the Channel, England (Ikeda I. 1912: Arch. Protistenkd. 25: 240-272) and the polychaete Nereis diversicolor O.F. Müller (Nereidae) from a Danish locality (Køie 2000: J. Parasitol. 86: 871-872).

Studies of marine polychaetes have shown that Spirorbis spirorbis (Linnaeus) (syn.: S. borealis Borg) (Spirorbidae) and Hydroides norvegica Gunnerus (Serpulidae) from Danish waters are infected with actinosporeans of unknown myxozoans.

In the northern Øresund, Denmark, the regularly coiled, calcareous tubes of $S$. spirorbis mostly occur on algae of the genera Fucus and Laminaria, whereas the larger, irregularly coiled, calcareous tubes of $H$. norvegica mostly are attached to the shells of live scallops. Spirorbis spirorbis exhibits a restricted breeding season during the warm months, whereas $H$. norvegica apparently breeds throughout most of the year. Algae with $S$. spirorbis and bivalves with $H$. norvegica were dredged at depths of about $15 \mathrm{~m}$ and $26-28 \mathrm{~m}$, respectively. The infections were not followed throughout the year, but $S$. spirorbis was found infected with actinosporean stages from March throughout the summer to September. Hydroides norvegica was found

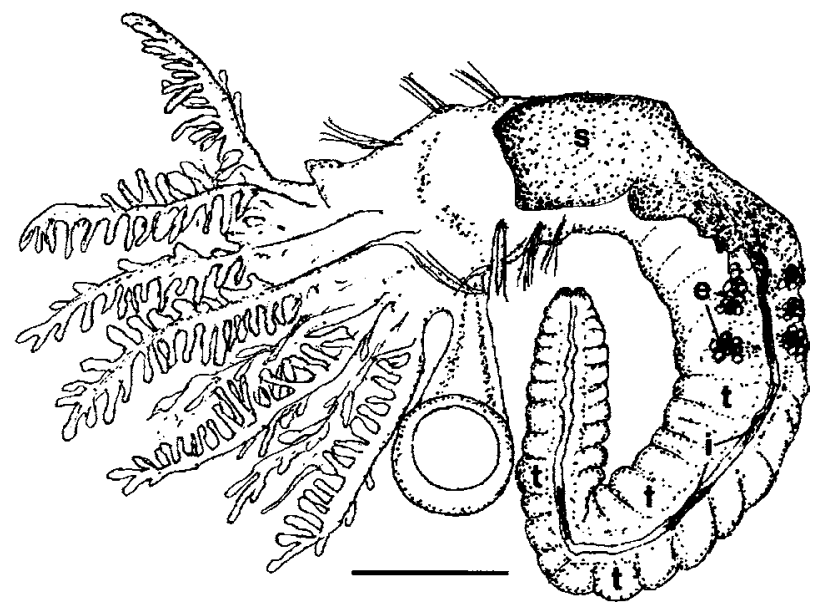

Fig. 1. Ventral view of a live flattened, slightly infected specimen of Spirorbis spirorbis removed from the calcareous tube. The pansporocysts occur in segments with the testes $(t)$ posterior to the ovaries. The eggs (e), stomach (s) and contents of the intestine (i) appear dark in transmitted light. Scale bar = $0.5 \mathrm{~mm}$.

infected with actinosporean stages in September and January. Experimental infections of various flatfishes and cod, Gadus morhua Linnaeus, have been unsuccessful.

In S. spirorbis and H. norvegica only pansporocysts and actinospores were found. In both polychaete species the actinosporean stages were found in the coelomic fluid of the segments with the male gonads only. Here the actinosporean stages and male polychaete gametocytes were found together. In heavily infected S. spirorbis these segments, which occupy the posterior segments of the abdomen (Fig. 1), were elongated and swollen. In both polychaete species the coelomic fluid of heavily infected specimens was packed with pansporocysts and actinospores but the gametocytes and spermatozoa never completely disappeared. The spermatozoa and actinospores were released together

Figs. 2-5. Live actinosporean stages from Spirorbis spirorbis. Figs. 2 and 3, interference contrast, Figs. 4 and 5, phase contrast, Figs. 3-5 to same scale. Fig. 2. Part of worm showing ovary with eggs (top) and male segments filled with pansporocysts (arrows). The free pansporocysts have been released by a rupture of the body wall. The dark contents of the intestine are seen to the right. Figs. 3, 4. Free pansporocysts removed from the coelom of male segments. Fig. 5. Free actinospores between spermatozoa (arrows). Figs. 6-12. Live actinosporean stages from Hydroides norvegica. All to same scale. Fig. 6, interference contrast, Figs. 7-12, phase contrast. Fig. 6. Two pansporocysts. Fig. 7. Pansporocyst showing the eight actinospores. Figs. 8-10. Actinospores removed from pansporocysts. Fig. 11. Actinospore showing its eight nuclei. Fig. 12. Actinospore released from the pansporocyst showing inflated epispores. e - egg; ep - epispore process or nucleus of epispore; ns - nucleus of sporoplasm; pc - polar capsule or nucleus of polar capsule cell. Scale bars: Fig. $2=50 \mu \mathrm{m}$; Figs. $3-5=10 \mu \mathrm{m}$; Figs. $6-12=5 \mu \mathrm{m}$. 


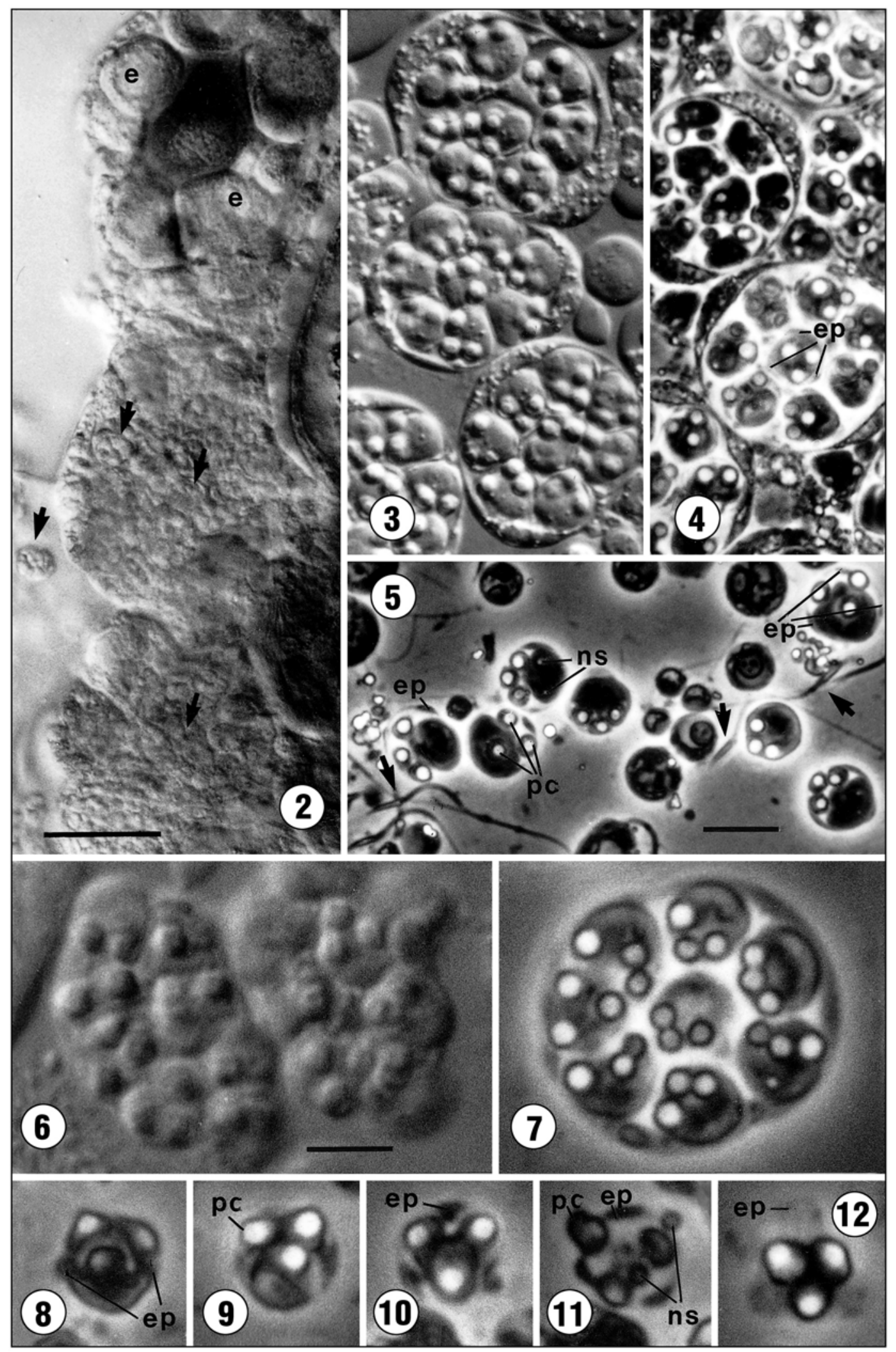


Table 1. Records of tetractinomyxon actinospores in invertebrates. Size in $\mu \mathrm{m}$.

\begin{tabular}{|c|c|c|c|c|c|c|c|}
\hline Hosts & $\begin{array}{l}\text { Name of } \\
\text { myxozoan } \\
\text { species }\end{array}$ & $\begin{array}{l}\text { Site of } \\
\text { infection }\end{array}$ & $\begin{array}{l}\text { Release of } \\
\text { actinosporeans }\end{array}$ & $\begin{array}{l}\text { Mature } \\
\text { pansporocyst }\end{array}$ & $\begin{array}{l}\text { Actino- } \\
\text { spore }\end{array}$ & $\begin{array}{l}\text { Polar } \\
\text { capsule }\end{array}$ & References \\
\hline $\begin{array}{l}\text { Spirorbis } \\
\text { spirorbis }\end{array}$ & unknown & $\begin{array}{l}\text { coelom of male } \\
\text { segments }\end{array}$ & $\begin{array}{l}\text { through } \\
\text { gonopores }\end{array}$ & $\begin{array}{l}\text { spherical } \\
20-30 \times 20-30\end{array}$ & $7-8 \times 7-8$ & $2.0 \times 2.0$ & present study \\
\hline $\begin{array}{l}\text { Hydroides } \\
\text { norvegica }\end{array}$ & unknown & $\begin{array}{l}\text { coelom of male } \\
\text { segments }\end{array}$ & $\begin{array}{l}\text { through } \\
\text { gonopores }\end{array}$ & $\begin{array}{l}\text { (sub)spherical } \\
15-20 \times 15-20\end{array}$ & $5-6 \times 5-6$ & $1.5 \times 1.5$ & present study \\
\hline $\begin{array}{l}\text { Nereis } \\
\text { diversicolor }\end{array}$ & unknown & $\begin{array}{l}\text { extraintestinal } \\
\text { tissue }\end{array}$ & $\begin{array}{l}\text { ingestion by next } \\
\text { host or upon } \\
\text { death of host }\end{array}$ & $\begin{array}{l}\text { elongate } \\
30-40 \times 20-30\end{array}$ & $\begin{array}{l}12-16 \times \\
10-12\end{array}$ & $3.5 \times 3.5$ & Køie 2000 \\
\hline $\begin{array}{l}\text { Manayunkia } \\
\text { speciosa }\end{array}$ & $\begin{array}{l}\text { Ceratomyxa } \\
\text { shasta }\end{array}$ & $\begin{array}{l}\text { extraintestinal } \\
\text { tissue }\end{array}$ & unknown & - & $11 \times 14$ & - & $\begin{array}{l}\text { Bartholomew } \\
\text { et al. } 1997\end{array}$ \\
\hline $\begin{array}{l}\text { Nephasoma } \\
\text { minuta }\end{array}$ & $\begin{array}{l}\text { unknown; } \\
\text { Tetractinomyxon } \\
\text { intermedium* }\end{array}$ & coelomic cavity & $\begin{array}{l}\text { through } \\
\text { nephridial funnel } \\
\text { and ventrolateral } \\
\text { pores (?) }\end{array}$ & $\begin{array}{l}\text { (sub)spherical } \\
20-30 \times 20-30\end{array}$ & $6.0 \times 6.0$ & $2.5 \times 2.5$ & Ikeda 1912 \\
\hline $\begin{array}{l}\text { Nephasoma } \\
\text { minuta }\end{array}$ & $\begin{array}{l}\text { unknown; } \\
\text { Tetractinomyxon } \\
\text { irregulare* }\end{array}$ & coelomic cavity & $\begin{array}{l}\text { through } \\
\text { nephridial funnel } \\
\text { and ventrolateral } \\
\text { pores (?) }\end{array}$ & - & $7.5 \times 7.5$ & - & Ikeda 1912 \\
\hline
\end{tabular}

*Name of actinosporean stages.

through the gonopores located laterally on each segment. In $S$. spirorbis the presence of the parasites did apparently not affect the development of the eggs (Fig. 2).

The pansporocysts in both polychaete species contained eight actinospores. Those in $S$. spirorbis were nearly spherical whilst those in $H$. norvegica were more irregularly shaped (Figs. 3, 4, $6,7)$. The pansporocyst wall consisted of two enveloping cells with flat nuclei. Measurements of pansporocysts and actinospores are provided in Table 1.

Recently released actinospores of both myxozoan species were subspherical, slightly flattened apically and spherical to conical basally. The three polar capsules were spherical and each surrounded by the polar capsule cell. In apical view the three epispore processes of actinospores within the pansporoblast appeared as small pointed projections each with a nucleus (Figs. $4,8-10)$. The epispore processes of actinospores released from $S$. spirorbis did not change appearance, whereas the processes of actinospores released from $H$. norvegica swelled on release into water reaching a maximum length of $3 \mu \mathrm{m}$ (Fig. 12). The binucleate sporoplasm could be seen in actinospores of both species (Figs. 5, 11).

The actinospores were of the tetractinomyxon type, identified by the presence of eight nuclei: three nuclei of the epispores,

Received 11 February 2002 three nuclei of the polar capsules and a binucleate sporoplasm (Figs. 5, 11) (Ikeda 1912, op. cit.; Janiszewska J. 1955: Acta Parasitol. Pol. 20: 405-437; Lom J., McGeorge J., Feist S.W., Morris D., Adams A. 1997: Dis. Aquat. Org. 30: 1-9; Bartholomew J.L., Whipple M.J., Stevens D.G., Fryer J.L. 1997: J. Parasitol. 83: 859-868).

Apart from the record of two species, Tetractinomyxon intermedium Ikeda, 1912 and the slightly larger T. irregulare Ikeda, 1912 in a sipunculid worm, tetractinomyxon spores have been recorded only in polychaetes (Table 1). In addition to the three species of marine polychaetes found infected, the freshwater polychaete Manayunkia speciosa Leidy (Sabellidae) acts as invertebrate host for Ceratomyxa shasta Noble, 1950 (Bartholomew et al. 1997, op. cit.).

Since the polychaetes most likely acquire the infection by ingesting myxospores, the actinosporean stages are most likely to occur in suspension-feeding polychaetes. Feeding by filtering through mucus nets (e.g., $N$. diversicolor) may be as efficient to retain myxospores as filtering by a branchial crown as is characteristic of the tube-dwelling Serpulimorpha, including the Serpulidae (e.g., H. norvegica), the Spirorbidae (e.g., S. spirorbis) and the Sabellidae (Jørgensen C.B. 1966: Biology of Suspension Feeding. Pergamon Press, Oxford, 357 pp).

Accepted 15 April 2002 